Research Article

\title{
Consolidation Characteristics of Artificially Structured Kaolin-Bentonite Mixtures with Different Pore Fluids
}

\author{
Nguyen Thanh Duong (iD) ${ }^{1}$ and Duong Van $\mathrm{Hao}^{2}$ \\ ${ }^{1}$ Hanoi University of Mining and Geology, Hanoi 100000, Vietnam \\ ${ }^{2}$ Institute of Research and Development, Duy Tan University, Da Nang 550000, Vietnam \\ Correspondence should be addressed to Nguyen Thanh Duong; nguyenthanhduong@humg.edu.vn
}

Received 18 June 2020; Revised 27 July 2020; Accepted 7 September 2020; Published 15 September 2020

Academic Editor: Claudia Vitone

Copyright (C) 2020 Nguyen Thanh Duong and Duong Van Hao. This is an open access article distributed under the Creative Commons Attribution License, which permits unrestricted use, distribution, and reproduction in any medium, provided the original work is properly cited.

\begin{abstract}
The consolidation characteristics of kaolin, bentonite, their mixtures, and natural clays have been widely evaluated. However, the effect of pore fluid on the consolidation characteristics of artificially structured kaolin-bentonite mixtures should be more investigated. In this study, the oedometer tests were carried out on mixtures of kaolin with $10 \%, 20 \%$, and $30 \%$ bentonite reconstituted with distilled water and $1 \mathrm{M} \mathrm{NaCl}$. The testing samples with an "artificial structure" were prepared using the preconsolidation procedure. The test results show that bentonite greatly affects the consolidation behavior of mixture samples, especially when the pore fluid is distilled water. In the case of distilled water, the addition of bentonite to kaolin clay significantly increased the compression index $\left(C_{c}\right)$, swelling index $\left(C_{s}\right)$, and coefficient of volume change $\left(m_{v}\right)$. In this case, the $m_{v}$ of mixture samples increased significantly at low effective axial stress $\left(\sigma_{a}^{\prime}\right)$ levels (less than the preconsolidation pressure) and then decreased as the $\sigma_{a}^{\prime}$ further increased. In the case of $1 \mathrm{M} \mathrm{NaCl}$ as the pore fluid, the $C_{c}$, $C_{s}$, and $m_{v}$ slightly changed with the increase of bentonite content. The research results also confirmed that the effect of saline water on the compression index was noticeable when the liquid limit of soil with distilled water was higher than $110 \%$, and the compression index of soil with distilled water was higher than 1. Regarding the coefficient of consolidation $\left(C_{v}\right)$, the $C_{v}$ of kaolin sample increased as the $\sigma_{a}^{\prime}$ increased, and this trend was independent of the pore fluid chemistry. By contrast, the $C_{v}-\sigma_{a}^{\prime}$ trend of mixture samples depended not only on the pore fluids but also on the stress level.
\end{abstract}

\section{Introduction}

The compressibility of clays is one of the most important aspects in geotechnical engineering, especially regarding the settlement calculation. It has been widely studied in terms of different clay minerals and different pore fluids [1-8]. The results indicated that there was a significant difference in the compression behavior of bentonite and kaolinite with different pore fluids. It may be attributed to the difference in surface charge and clay mineral structures [7, 9-14]. For bentonite, the compression behavior accords with the double layer theory and strongly depends on the pore fluid chemistry. The increase in ion valence and ion concentration of the pore fluid leads to a decrease of the compressibility and swelling ability. For kaolinite, the pore fluid also affects the compressibility but with a smaller degree than for bentonite. Robinson and Allam [7] and Sridharan and Rao [8] noted that the compressibility of kaolinite was mainly governed by mechanical factors, while it of bentonite was mostly controlled by physicochemical effects. However, Chen et al. [3] noted that the compressibility and swelling of kaolinite were controlled by both chemical and physicochemical factors. The compressibility of kaolinite was independent of pore fluid properties under stresses of $300 \mathrm{kPa}$. The controlling factors of compression may affect the consolidation coefficient $\left(C_{v}\right)$. Robinson and Allam [7] showed that the $C_{v}$ increased with consolidation pressures when the controlling factor of compression behavior was mechanical and decreased with consolidation pressure when the controlling factor was physicochemical. Recently, Dutta 
and Mishra [5] investigated the consolidation behavior of bentonite mixed with different salt solutions. The research results showed that the consolidation parameters, including $C_{c}$, coefficient of volume change $\left(m_{v}\right)$, and $t_{90}(90 \%$ of consolidation) of the bentonite, decreased while $C_{v}$ increased with the increase of salt concentration. Moreover, the $C_{v}$ decreased as the consolidation pressure increased regardless of the salt solution.

The consolidation behavior of kaolin-bentonite mixtures has also been examined. Di Maio et al. [4] studied the consolidation behavior of kaolin-bentonite mixtures and natural soils mixed with distilled water and indicated that the mineral compositions, especially smectite, had a significant effect on the volume change behavior. Fan et al. [15] investigated the compression behavior of kaolinite-Ca-bentonite mixtures using for wall backfill. The samples were mixed with distilled water at different initial water contents. The research results showed that the compressibility depended significantly on the initial water content and bentonite content. Besides, they indicated the existence of the remolded yield stress on the inverse " $S$ " shape of compression curves, and it had a unique correlation with $e_{1}$ (void ratio at $1 \mathrm{kPa}$ ). Recently, Lodahl and Sørensen [16] examined the effects of pore water chemistry on the unloading-reloading behavior of reconstituted kaolinbentonite mixtures. The research results showed a significant effect of smectite mineral, pore water salinity, and cation valence in the pore fluid on the volumetric compression in both virgin state and overconsolidated conditions.

From the literature, it can be seen that the reconstituted samples of kaolin, bentonite, and their mixtures have widely been used to investigate the consolidation characteristics of soil since kaolinite and bentonite are two of common clay mineral types in soil. In addition, bentonite is commonly used in civil engineering applications such as the slurry wall, cutoff wall, and barriers in landfill $[1,15,17-21]$. Besides the reconstituted samples, the undisturbed samples were often used to investigate the consolidation behavior of natural clays. However, for undisturbed samples of natural clays, the effect of pore fluid chemistry on the consolidation characteristics was often examined using the intrusion or leaching procedures [22-28]. Thus, the reconstituted samples are commonly used to investigate the effect of pore fluid chemistry with different concentrations on the consolidation behavior of soils.

In general, the consolidation characteristics of reconstituted kaolin, bentonite, their mixtures, and natural clays have been widely investigated. Nevertheless, the samples were often prepared by mixing with distilled water or saline water at their liquid limits in the form of a slurry and packed into the oedometer rings in thin layers or at the optimum water content and then compacted in the oedometer ring. These procedures may lead to the existence of air bubbles within the soil sample. In this study, the preconsolidation procedure using a consolidation tank will be employed to prepare samples for oedometer tests. Accordingly, the mixtures of commercial kaolin and bentonite were mixed with distilled water and $1 \mathrm{M} \mathrm{NaCl}$ in the form of a slurry and then preconsolidation in the consolidation tank under a certain pressure. In this case, these preconsolidation samples showed an "artificial structure" and were used as testing samples. The 1D consolidation test was employed to investigate the consolidation behavior of these samples. In this investigation, the consolidation parameters, including compression index $\left(C_{c}\right)$, swelling index $\left(C_{s}\right)$, coefficient of volume change $\left(m_{v}\right)$, and coefficient of consolidation $\left(C_{v}\right)$ of kaolin and kaolinbentonite mixtures with distilled water and $1 \mathrm{M} \mathrm{NaCl}$ in the pore fluids, were reported and evaluated. The factors governing these parameters were also discussed.

\section{Materials and Methods}

In this study, commercial kaolin and bentonite widely consumed in Japan were used. The physical properties of kaolin and bentonite are shown in Table 1.

The sample mixtures were created by mixing $90 \%, 80 \%$, and $70 \%$ kaolin with $10 \%, 20 \%$, and $30 \%$ bentonite (dry weight), respectively. Kaolin and kaolin-bentonite mixtures were mixed with distilled water and $1 \mathrm{M} \mathrm{NaCl}$ solution in the form of a slurry at about 2 times their liquid limits. According to the research results of Di Maio et al. [4], the compression index of some clays, including Ponza bentonite, Bisaccia clay, Marino clay, and kaolin, was almost unchanged when the concentration of $\mathrm{NaCl}$ solution in the pore fluid was higher than or equal to $1 \mathrm{M}$. The slurry sample was then stored in the humidity chamber for $24 \mathrm{~h}$ at room temperature $\left(20 \pm 2^{\circ} \mathrm{C}\right)$ to prevent the loss of moisture content and reach a homogeneous state. The doubledraining consolidation tank with an inner diameter of $15 \mathrm{~cm}$ and a height of $30 \mathrm{~cm}$ was employed for sample preparation (Figure 1). The inside wall of the consolidation tank was highly cleaned and coated by a thin layer of petroleum jelly to minimize the friction force between the wall and the soil samples and to easily extrude samples after consolidation. The slurry was transferred into the consolidation tank using a spoon, and a vacuum pressure of $70 \mathrm{kPa}$ was applied for about $1 \mathrm{~h}$ to release the air bubbles trapped in the slurry. As reported, the water content of remolded samples for the oedometer test should be closed to the liquid limit to mitigate the effect of initial water content on results $[5,17-19,29]$. Thus, in this study, the vertical load of $45 \mathrm{kPa}$ will be applied to consolidate the slurry in the tank to produce the preconsolidation samples, which have the water content closed to the liquid limit. The consolidation process would be finished until the end of the primary consolidation, which was confirmed by judgment based on the $3 t$-method $[30,31]$. The method has been widely used for the preparation of preconsolidation samples in the laboratory test in Japan [32-34]. After finishing the consolidation process in the tank, the vertical load was unloaded, and the cylindrical tank containing the sample was removed from the top and bottom plates. Since the inside wall of the cylindrical tank existed a thin layer of petroleum jelly, the sample was easily pushed out by hand. The specimens to be used in the oedometer tests were cut from the preconsolidation samples using a cutter ring with a height of $2 \mathrm{~cm}$ and an inner diameter of $6 \mathrm{~cm}$. The oedometer tests were carried out according to a Japanese standard (JGS 0411-2009) [35]. 
TABLe 1: Physical properties of kaolin and bentonite.

\begin{tabular}{lccccc}
\hline Sample & Specific density, $\rho_{s}\left(\mathrm{~g} / \mathrm{cm}^{3}\right)$ & Liquid limit, $w_{L}(\%)$ & Plasticity index, $I_{P}$ & Clay fraction, CF (\%) & Activity index, $A(-)$ \\
\hline Kaolin & 2.645 & 77.5 & 42.1 & 46 & 0.92 \\
Bentonite & 2.759 & 405 & 351.3 & 62 & 5.66 \\
\hline
\end{tabular}

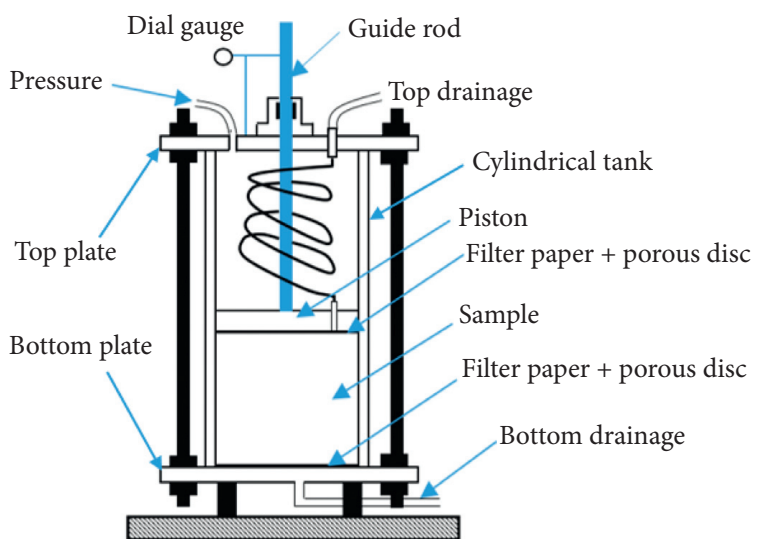

FIgURE 1: Consolidation tank for sample preparation.

Some physical properties of testing samples are shown in Table 2. In this table, the water content was determined following ASTM D2216-10 [36] using the oven drying method. The Atterberg limits of testing samples were determined according to ASTM D4318-10 [37]. It should be noted that in the case of $1 \mathrm{M} \mathrm{NaCl}$ as the pore fluid (saline soil sample), the conventional method for determination of water content may give the erroneous results since the dissolved salt remains with soil solids when the pore water evaporates [38]. Thus, in this study, to eliminate the errors, the water content and Atterberg limits of saline soil samples were calculated and determined as the procedure shown in Noorany [38]. Accordingly, the water content was corrected based on the converting formula with salinity content $(r)$ of $5.8 \%(1 \mathrm{M} \mathrm{NaCl})$, and $1 \mathrm{M} \mathrm{NaCl}$ solution was used to determine the Atterberg limits of saline soil samples. Before applying a load, the same solution as the pore fluid in the soil sample was poured into the oedometer cell to prevent the leaching of salt from soil sample to the cell solution, and the entire consolidation cell was covered by a plastic bag to prevent evaporation during testing [3, 5, 17-19]. The tests were performed according to the Japanese standard [35] and at the room temperature of $20 \pm 2^{\circ} \mathrm{C}$.

\section{Test Results and Discussion}

3.1. Compression and Swelling Behavior. Consolidation test results of samples with distilled water and $1 \mathrm{M} \mathrm{NaCl}$ as the pore fluids are shown in Figures 2(a) and 2(b). As can be seen from these figures, the mixtures with higher bentonite content showed higher void ratios and faster deformation levels at low pressures. However, this trend was almost diminished at high pressures. The decrease of the void ratio at low pressures was remarkable when the pore fluid was distilled water. In the case of distilled water as the pore fluid, the compression curves of mixture samples exhibit an inverse "S" shape, which is clearer for the mixtures with bentonite content more than $10 \%$. The inverse " $\mathrm{S}$ " shape was also found in the remolded clayey soils $[39,40]$, in the Nabentonite slurry [41], and in the Ca-bentonite slurry for wall backfill (with bentonite content from 10\% to 15\%) [15].

From $e-\log \sigma_{a}^{\prime}$ curves, the yield stress (preconsolidation pressure) is determined based on the method of Casagrande [42] and denoted as "apparent yield stress." As shown, the apparent yield stress value of all samples tends to decrease as the bentonite content increases. Furthermore, the apparent yield stress in the case of distilled water (Figure 2(a)) is lower than that in the case of $1 \mathrm{M} \mathrm{NaCl}$ as the pore fluid (Figure 2(b)). As mentioned above, all samples were first subjected to a consolidation pressure of $45 \mathrm{kPa}$ in the consolidation tank until the end of primary consolidation, so the yield stress (preconsolidation pressure, Pc), theoretically, should be equal to $45 \mathrm{kPa}$ regardless of the effect of sampling and load increments. However, the value of apparent yield stress for samples with distilled water in the pore fluid is smaller than the calculated value of $45 \mathrm{kPa}$, except for kaolin sample (Figure 2(a)), whereas it for samples with $1 \mathrm{M} \mathrm{NaCl}$ in the pore fluid is higher than $45 \mathrm{kPa}$ (Figure 2(b)). The differences between apparent and calculated yield stresses and the decrease of apparent yield stress with increasing bentonite content can be explained based on the modified effective stress concept at the particle level as proposed by Sridharan and Prakash [43]. In the case of distilled water as the pore fluid, the diffuse double layer (DDL) thickness of mixture samples is large; so, the repulsive forces dominate, resulting in low modified effective stress, and this, in turn, decreases the apparent yield stress to lower than the calculated value $[26,44,45]$. In the case of $1 \mathrm{M} \mathrm{NaCl}$ as the pore fluid, the attractive force will dominate due to the decrease of DDL thickness and results in an increase of the modified effective stress. Although the overburden stress is removed by sampling, the internal effective stress still existed within the soil sample [45]. Thus, in this case, the increase of modified effective stress will increase the apparent yield stress to higher than the calculated value. Besides, in both cases of distilled water and $1 \mathrm{M} \mathrm{NaCl}$, the decrease of apparent yield stress with the bentonite content is attributed to the decrease of modified effective stress as the bentonite content increases.

The change of coefficient of compressibility $\left(C_{c}\right)$ and swelling index $\left(C_{s}\right)$ with different bentonite proportions and pore fluids are shown in Figure 3. It is well known that compression and swelling behavior depends much on the DDL thickness. The DDL thickness around smectite particles in distilled water is much higher than that around kaolinite particles $[10,11,13,14]$. As reported by Sridharan and Rao [8], there are two factors controlling the volume change characteristics of clays, namely shearing resistance 
TABLE 2: Some physical properties of testing specimens.

\begin{tabular}{|c|c|c|c|c|c|c|}
\hline Pore fluids & $\%$ bentonite & $\begin{array}{c}\text { Liquid limit, } w_{L} \\
(\%)\end{array}$ & $\begin{array}{c}\text { Plasticity index, } I_{P} \\
(\%)\end{array}$ & $\begin{array}{c}\text { Water content, } w_{0} \\
(\%)\end{array}$ & $\begin{array}{l}\text { Initial void ratio, } \\
e_{0}\end{array}$ & $\begin{array}{l}\text { Bulk unit weight, } \gamma \\
\left(\mathrm{g} / \mathrm{cm}^{3}\right)\end{array}$ \\
\hline \multirow{4}{*}{$\begin{array}{l}\text { Distilled } \\
\text { water }\end{array}$} & 0 & 77.5 & 42.1 & 75.1 & 1.989 & 1.55 \\
\hline & 10 & 112 & 77.1 & 100.2 & 2.660 & 1.45 \\
\hline & 20 & 136 & 99.7 & 121.6 & 3.250 & 1.39 \\
\hline & 30 & 172 & 129.1 & 156.8 & 4.239 & 1.31 \\
\hline \multirow{4}{*}{$1 \mathrm{M} \mathrm{NaCl}$} & 0 & 64 & 30.0 & 63.1 & 1.661 & 1.62 \\
\hline & 10 & 73 & 40.4 & 65.0 & 1.728 & 1.61 \\
\hline & 20 & 75 & 42.8 & 67.4 & 1.791 & 1.60 \\
\hline & 30 & 77.5 & 44.5 & 68.5 & 1.846 & 1.59 \\
\hline
\end{tabular}

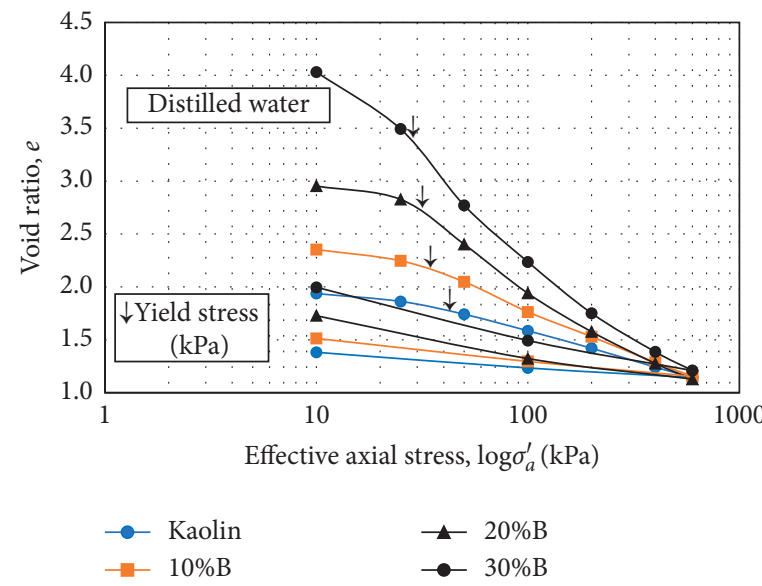

(a)

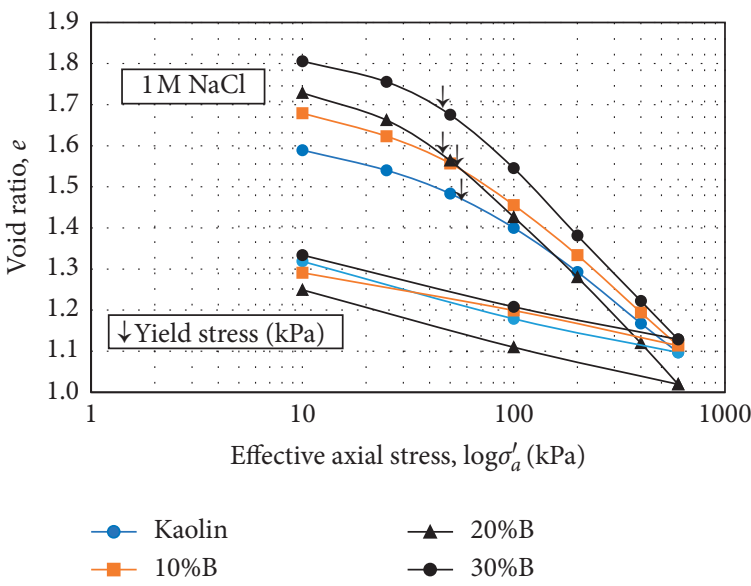

(b)

Figure 2: Void ratio-effective axial stress relationship. (a) Distilled water; (b) $1 \mathrm{M} \mathrm{NaCl}$.

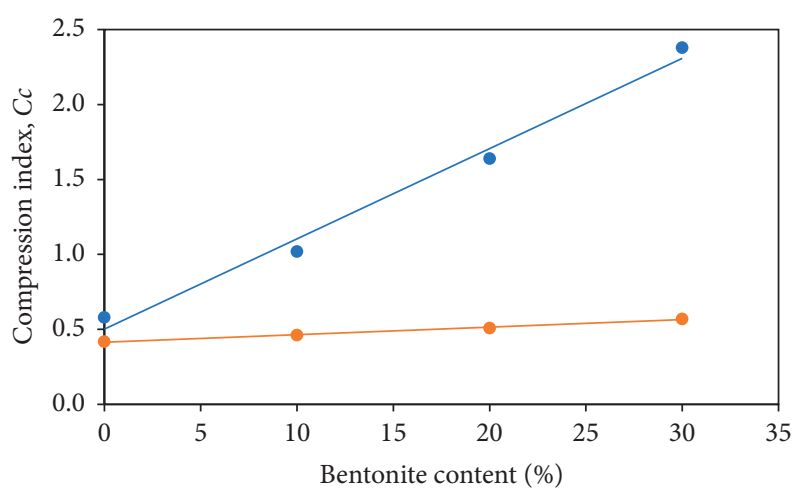

- Distilled water

- $1 \mathrm{M} \mathrm{NaCl}$

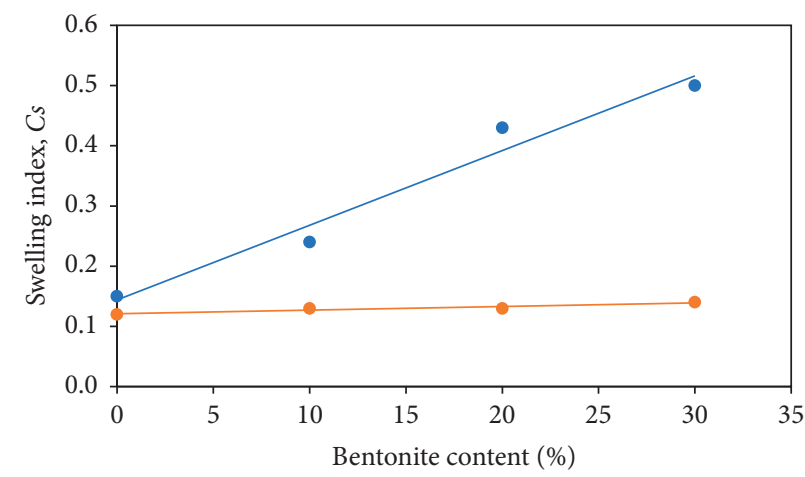

- Distilled water

- $1 \mathrm{M} \mathrm{NaCl}$

(a)

(b)

FIGURE 3: Influence of bentonite content on the compression and swelling indices.

and DDL repulsive forces, in which, the DDL repulsive forces play an important role in explaining the compressibility behavior, especially for smectite mineral $[6,8,10]$. Therefore, higher bentonite content leads to higher compressibility and swelling ability. The $C_{c}$ and $C_{s}$ increased significantly with an increase in bentonite content when the pore fluid was distilled water (Figure 3(a)). This indicates that, in the case of distilled water, the compression and swelling behaviors of mixture samples depend much on bentonite content and are mainly governed by 
physicochemical factors. Figure $3(\mathrm{~b})$ presents that the $C_{c}$ increases slightly with increasing bentonite content when the pore fluid is $1 \mathrm{M} \mathrm{NaCl}$, while the $C_{s}$ is almost unchanged. It reveals that, in the case of $1 \mathrm{M} \mathrm{NaCl}$, compression and swelling behaviors are mostly controlled by mechanical factors. This attributed to the DDL is almost suppressed at high ion concentration of $1 \mathrm{M}$ [5]. The $C_{c}$ and $C_{s}$ values of kaolin are almost similar in both cases of distilled water and $1 \mathrm{M} \mathrm{NaCl}$ as the pore fluids. This confirms that the behavior of kaolin is mainly controlled by mechanical effects [7, 8]. It can be seen that the behavior in compression and swelling of mixture samples mixed with $1 \mathrm{M} \mathrm{NaCl}$ is similar to that of kaolin.

Figure 4 shows the relationship between the normalized compression and swelling indices concerning the pore fluid and bentonite content. As shown in Figure 4 , the $C_{c}$ and $C_{s}$ of mixture samples decrease significantly when the pore fluid is $1 \mathrm{M} \mathrm{NaCl}$. Additionally, the normalized swelling and compression indices decrease notably with $10 \%$ bentonite. This indicates that $10 \%$ of bentonite is sufficient to change the $C_{c}$ and $C_{s}$ dramatically.

The relationship between the normalized compression and swelling indices concerning the pore fluid and liquid limit of clay with distilled water is shown in Figure 5. The data in Figure 5 are collected from previous studies. Yukselen-Aksoy et al. [29] investigated the effect of seawater on the compressibility characteristics of different clays. Di Maio et al. [4], Mishra et al. [17], and Shariatmadari et al. [20] examined the effect of saline water with the concentration of $1 \mathrm{M}$ in the pore fluid on the compressibility characteristics of clay. As shown in Figure 5, the effect of $1 \mathrm{M} \mathrm{NaCl}$ on the compressibility characteristics of kaolin-bentonite mixtures in this study (pink symbol) is noticeable when the liquid limit for distilled water, $w_{L}$, is higher or equal to $112 \%$ (a mixture of $10 \%$ bentonite and $90 \%$ of kaolin). This has confirmed the research finding of Yukselen-Aksoy et al. [29] that the effect of saline water on the compressibility characteristics was significant when the liquid limit of soil for distilled water was higher than $110 \%$.

The relationship between the compression index of soil with saline water and distilled water as the pore fluids is shown in Figure 6. The data in Figure 6 are collected from the previous study, which investigated the compression index of soil with saline water concentration up to $1 \mathrm{M}$ $[4,17,20,29,46]$. The dotted line in Figure 6 shows that the compression index of soil with saline water $\left(C_{c \text { (Saline) }}\right)$ is almost equal to that of soil with distilled water $\left(C_{c \text { (Distilled) }}\right)$. This indicates that when the $C_{c \text { (Distilled) }}$ is lower than 1 , the effect of saline water in the pore fluid on the compression index is insignificant. By contrast, as shown by the continuous line, the $C_{c}$ (saline) is significantly lower than the $C_{c}$ (distilled). In other words, when the $C_{c}$ (distilled) is higher than 1 , the effect of saline water on the compression index is noticeable. As indicated by Tiwari and Ajmera [46], two different correlations here can be attributed to the presence of smectite mineral in soil samples. According to their research results, the salt solution, $\mathrm{NaCl}$ affects significantly the compression behavior of smectite-dominated soils. In particular, the compression indices of soil samples having

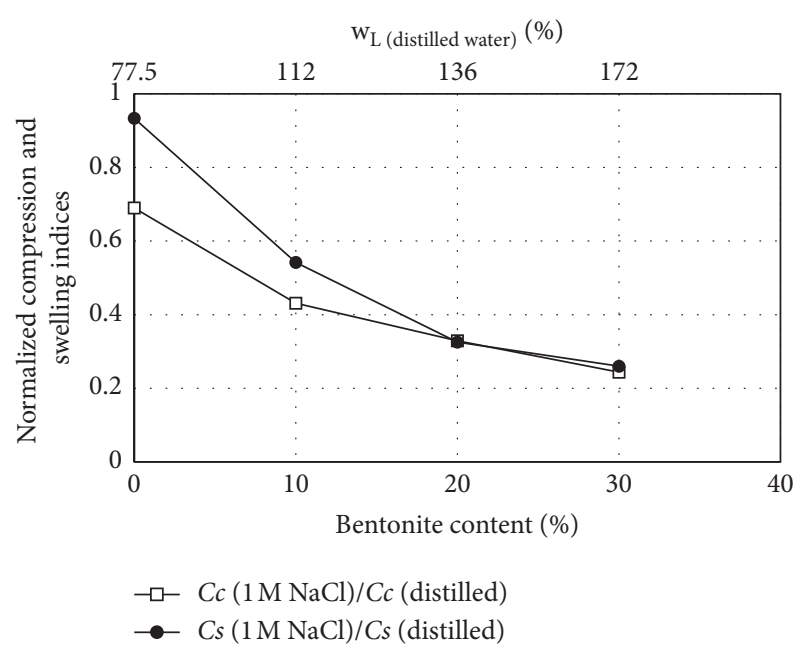

Figure 4: The relationship between the normalized compression and swelling indices concerning the pore fluid and bentonite content.

smectite content above $10 \%$ can be decreased by up to $77 \%$ when at treatment with $0.5 \mathrm{M} \mathrm{NaCl}$. By contrast, the effect of $\mathrm{NaCl}$ on the compression behavior of kaolinite- and illitedominated soils is not significant with the decrease of compression indices of about $10 \%$. Similarly, in this study, the effect of $1 \mathrm{M} \mathrm{NaCl}$ on the compression index of kaolin is also insignificant, whereas this effect is noticeable when $10 \%$ bentonite is added. Thus, the presence of smectite mineral in soil significantly affects the effect of salt on the compression behavior of soil.

3.2. Coefficient of Volume Change $\left(m_{v}\right)$. The variation of coefficient of volume change $\left(m_{v}\right)$ with consolidation pressure for kaolin and kaolin-bentonite mixtures in the presence of distilled water and $1 \mathrm{M} \mathrm{NaCl}$ is shown in Figure 7. As shown in Figure 7(a), in the presence of distilled water, the $m_{v}$ of kaolin is almost unchanged at low pressures of less than $50 \mathrm{kPa}$ (at normally consolidated state), and then, it decreases as the consolidation pressures increase. By contrast, the $m_{v}$ of kaolin-bentonite mixtures initially increases, and then, it decreases with the increase in the consolidation pressures. In particular, for $30 \mathrm{~B}$ sample, the $m_{v}$ increases significantly at effective axial stress of less than $25 \mathrm{kPa}$ and decreases with increasing effective axial stress above $25 \mathrm{kPa}$. For $10 \mathrm{~B}$ and $20 \mathrm{~B}$ samples, the $m_{v}$ increases with effective axial stress up to $50 \mathrm{kPa}$, and then, it shows a declining tendency. It should be noted that all samples were preconsolidated at an effective axial stress of $45 \mathrm{kPa}$; so, in theoretical, the volume change (compressibility) at effective axial stress of less than this value was small [40]. However, for mixture samples mixed with distilled water, the DDL thickness is large, the repulsive forces at particle level are dominant, and the void ratio is high at low effective axial stress levels. Thus, the increase of the effective axial stress at the low range can lead to a significant reduction of the void and increases the $m_{v}$ [5]. After reaching the peak value, the coefficient of volume change decreases with the increase of effective axial stress. 


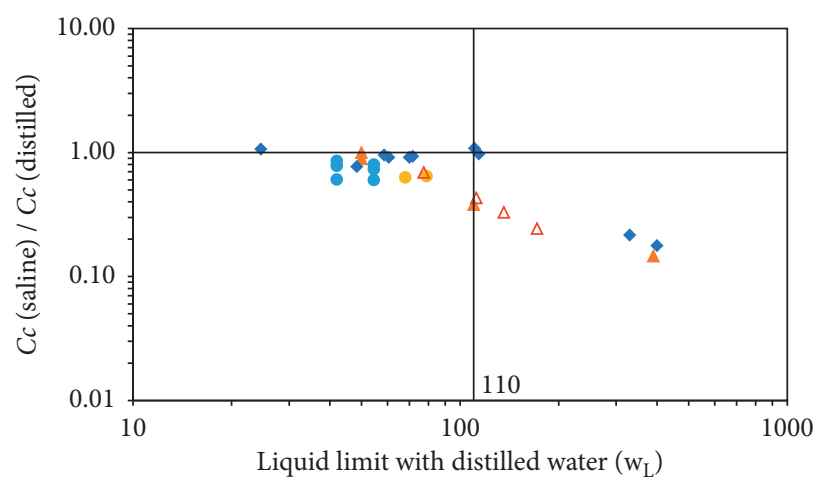

^ Di maio et al., 2004 (<5-80\% smectite)

- Mishra et al., 2005 (10-20\% bentonite)

- Yukselen-aksoy et al., 2008

- Shariatmadari et al., 2011 (10-20\% bentonite)

$\Delta$ This study (10-30\% bentonite)

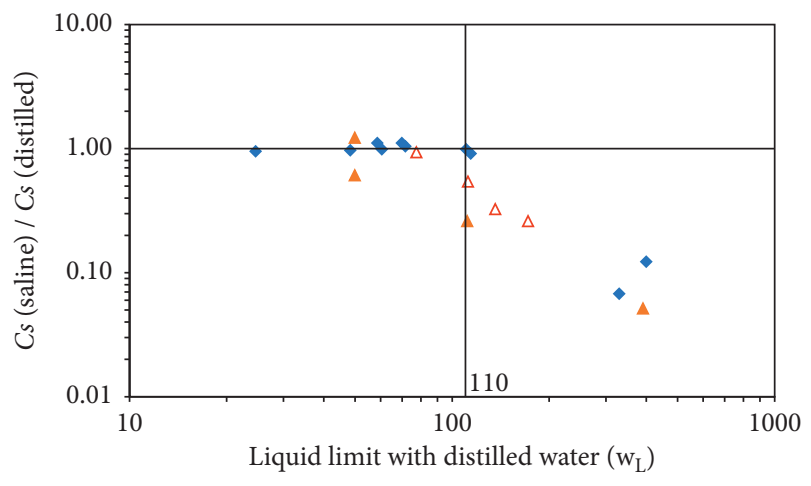

^ Di maio et al., 2004 (< 5-80\% smectite)

- Yukselen-aksoy et al., 2008

$\Delta$ This study (10-30\% bentonite)

(a)

(b)

FIGURE 5: The relationship between the normalized swelling and compression indices concerning the pore fluid and liquid limit of clays in distilled water.

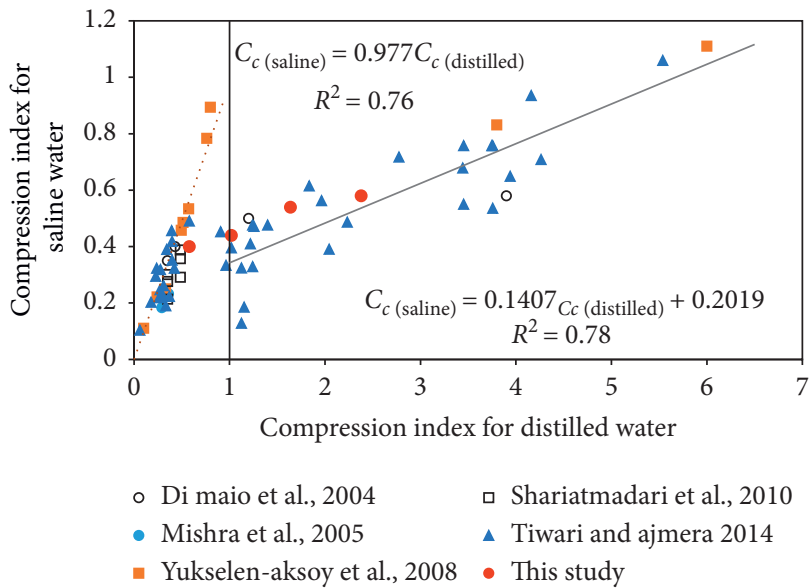

Figure 6: Relationship between compression index for $\mathrm{NaCl}-$ treated and untreated soil samples.

As shown in Figure 7(b), in the presence of $1 \mathrm{M} \mathrm{NaCl}$, the $m_{v}$ of all samples tends to decrease with increasing effective axial stress. Since the DDL thickness is small in the case of $1 \mathrm{M} \mathrm{NaCl}$, the effect of DDL on the volume change is insignificant [5]. In this case, the preconsolidation pressure in the tank has no effect on the $m_{v}-\sigma_{a}^{\prime}$ tendency. In both cases of distilled water and $1 \mathrm{M}$ $\mathrm{NaCl}$ as the pore fluids, the $m_{v}$ increases with the increase of bentonite content, especially at low pressures. The increase of bentonite content leads to an increase in DDL thickness and void ratio, and this results in a high $m_{v}$ [5]. Besides, as shown in Figures 7(a) and 7(b), the volume change coefficients of all samples slightly change with increasing bentonite contents at an effective axial stress of higher than or equal to $400 \mathrm{kPa}$ since the void ratios and DDL thickness are small at above this stress.
3.3. Coefficient of Consolidation $\left(C_{v}\right)$. The coefficient of consolidation $\left(C_{v}\right)$ was determined based on the square root of the time fitting method (Taylor's method) [47]. The $\log C_{v}-\sigma_{a}^{\prime}\left(C_{v}-\sigma_{a}^{\prime}\right)$ relationship is shown in Figure 8. As shown in Figure 8(a), the $C_{v}-\sigma_{a}^{\prime}$ trend with distilled water in the pore fluid inversely changes when bentonite is added to kaolin clay. This indicates that the clay mineral significantly affects the $C_{v}-\sigma_{a}^{\prime}$ trend, especially in the case of distilled water. Moreover, as with the tendency of $m_{v}$ (Figure $7(\mathrm{a})$ ), the $C_{v}$ of $30 \mathrm{~B}$ sample sharply decreases at effective axial stress below $25 \mathrm{kPa}$ and that of $10 \mathrm{~B}$ and $20 \mathrm{~B}$ samples decreases with increasing effective axial stress up to $50 \mathrm{kPa}$ (Figure 8(a)). This reveals that the $m_{v}$ and $C_{v}$ of mixture samples with distilled water in the pore fluid significantly decrease at stress levels less than the apparent yield stress (at overconsolidated state). The difference here can be due to the factors controlling the compressibility characteristics of kaolin and kaolin-bentonite mixture samples. The main controlling factors of mixture samples mixed with distilled water are physicochemical since the DDL thickness of these samples is large. In particular, the physicochemical effect is pronounced at low stresses and high void ratios $[7,11]$. In the case of distilled water, the DDL thickness and void ratio of mixture samples are large at low stresses, and as mentioned above, the increase in effective axial stress at the low range leads to an increase in volume change coefficient $\left(m_{v}\right)$ (Figure $\left.7(\mathrm{a})\right)$. This phenomenon is also observed for bentonite in the presence of different pore fluids [5]. Since the $C_{v}$ is inversely proportional to the $m_{v}$, the significant increase of $m_{v}$ at low stresses will lead to a rapid reduction in the $C_{v}$. After decreasing to the minimum value, the $C_{v}$ increases slightly or is almost unchanged with increasing effective axial stress. This may be attributed to the similar reduction in both permeability $(k)$ and the coefficient of volume change $\left(m_{v}\right)$ [48]. 


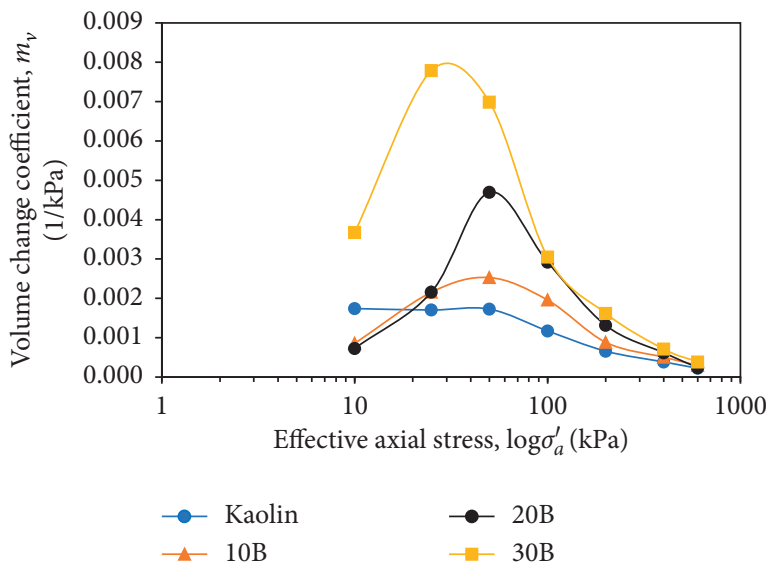

(a)

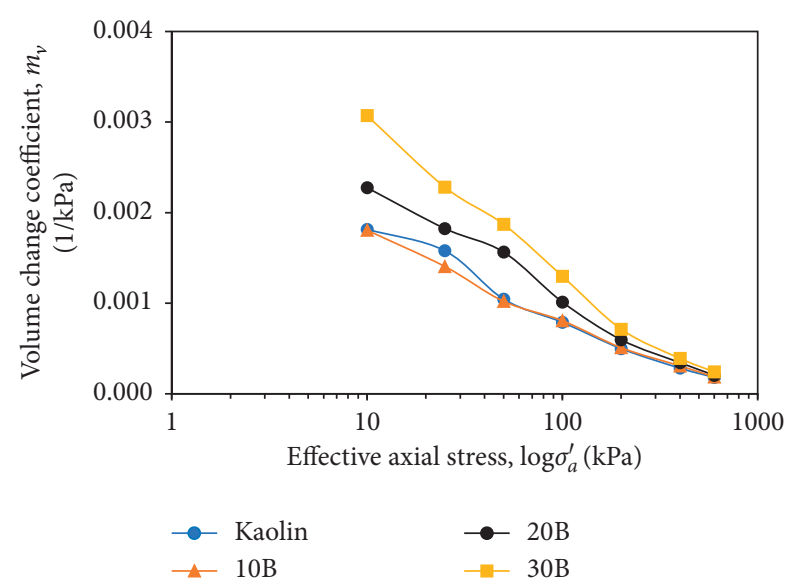

(b)

FIgURE 7: Variation of the coefficient of volume change $\left(m_{v}\right)$ with effective axial stress. (a) Distilled water; (b) $1 \mathrm{M} \mathrm{NaCl}$.

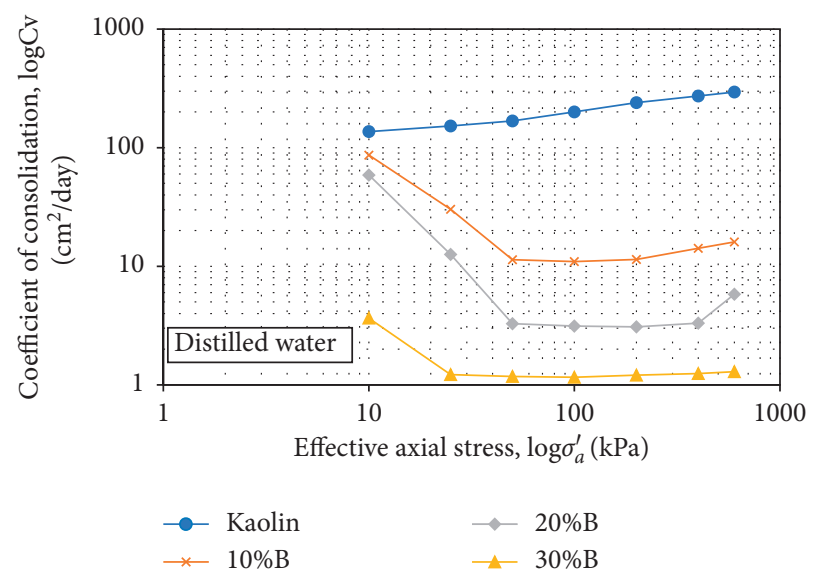

(a)

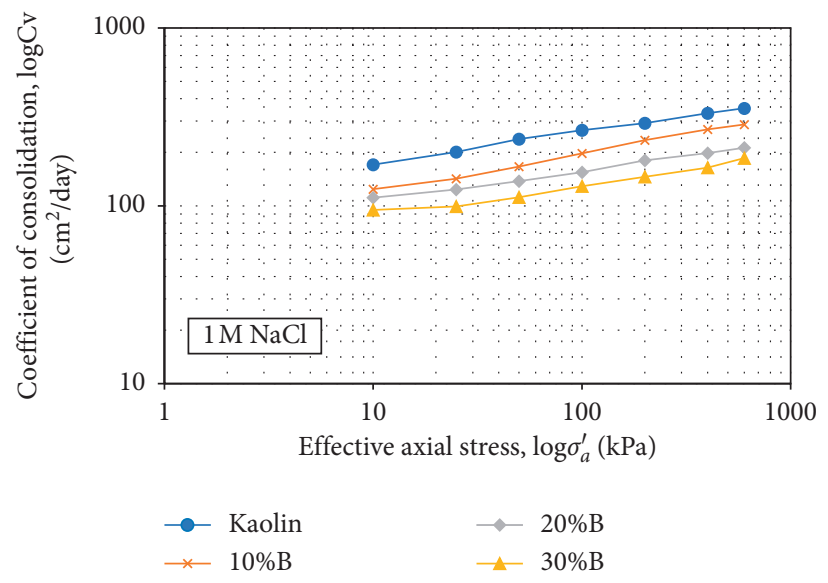

(b)

FIgURE 8: Variation of $C_{v}$ with effective axial stress. (a) Distilled water; (b) $1 \mathrm{M} \mathrm{NaCl}$.

In Figure $8(\mathrm{~b})$, the $C_{v}$ for all samples mixed with $1 \mathrm{M}$ $\mathrm{NaCl}$ shows an increasing trend with the effective axial stress. In this case, the preconsolidation pressure in the tank does not affect the $C_{v}-\sigma^{\prime}{ }_{a}$ trend. This trend is similar to that of the kaolin sample with distilled water in the pore fluid (Figure $8(\mathrm{a})$ ). The trend of $C_{v}-\sigma^{\prime}{ }_{a}$ here can be attributed to the main controlling factors of kaolin, and mixture samples mixed with $1 \mathrm{M} \mathrm{NaCl}$ are mechanical and result in increasing $C_{v}$ with effective axial stress [7]. In general, the $C_{v}-\sigma_{a}^{\prime}$ relationship of the kaolin sample shows an increasing trend and is independent of the pore fluid chemistry. By contrast, the $C_{v}-\sigma_{a}^{\prime}$ trend of mixture samples significantly depends on the pore fluid chemistry. Accordingly, with distilled water in the pore fluid, the tendency of $C_{v}$ of mixture samples depends on the effective axial stress levels, whereas with $1 \mathrm{M} \mathrm{NaCl}$ in the pore fluid, the $C_{v}$ of mixture samples increases with the effective axial stress, regardless of its levels.

The results of the $C_{v}-\sigma^{\prime}{ }_{a}$ trend in this study contradict the statement of Terzaghi et al. [48]. Terzaghi et al. predicted that the $C_{v}$ was almost unchanged over a wide range of effective axial stress since both the permeability $(k)$ and $m_{v}$ decreased as the consolidation pressures increased. However, previous studies show that the $C_{v}$ is not constant over the range of effective axial stress [7, 49-51]. It can be increased or decreased with increasing stress depending on the clay mineralogical compositions. In this study, the result of $C_{v}-\log \sigma_{a}^{\prime}$ relationship also shows that the $C_{v}$ may increase or decrease with the increase of effective axial stress depending on the mineral compositions and stress levels. Moreover, the research result of this study also shows that the pore fluid chemistry significantly affects the $C_{v}-\sigma_{a}^{\prime}$ trend, especially for kaolin-bentonite mixture samples.

\section{Conclusions}

In this study, the effect of pore fluids on the compressibility characteristics of kaolin-bentonite mixtures prepared using the preconsolidation procedure had been extensively 
investigated. Based on the analysis of the test results, some conclusions are drawn as follows:

The compression and swelling behavior of kaolin-bentonite mixtures depended on the behavior of smectite mineral to the pore fluids, especially when the pore fluid was distilled water. In the case of distilled water, the compression curves of mixture samples showed an inverse " $S$ " shape. The apparent yield stress of preconsolidation samples could be lower or higher than the calculated one depending on the mineral compositions and pore fluid chemistry.

Regarding the consolidation parameters, the addition of bentonite led to a significant increase of $C_{c}, C_{s}$, and $m_{v}$ of kaolin-bentonite mixtures, especially in the case of distilled water in the pore fluid. In this case, the $m_{v}$ of mixture samples increased at low effective axial stress $\left(\sigma_{a}^{\prime}\right)$ levels, and then, it decreased as the stresses further increased, while the $m_{v}$ of kaolin sample showed a decreasing trend with the increase of $\sigma_{a}^{\prime}$. By contrast, when the pore fluid was $1 \mathrm{M}$ $\mathrm{NaCl}$, the $m_{v}$ of kaolin and mixture samples showed a decreasing trend with increasing $\sigma_{a}^{\prime}$. This indicates that the $m_{v}-\sigma_{a}^{\prime}$ trend depends on mineral compositions, pore fluid chemistry, and stress levels. The research results have confirmed that the effect of saline water on the compression index is significant when the soil had the liquid limit with distilled water higher than about $110 \%$ and the compression index with distilled water higher than 1 .

The coefficient of consolidation $\left(C_{v}\right)$ of the kaolin sample increased with the increase of $\sigma^{\prime}{ }_{a}$ regardless of the pore fluid chemistry. However, for mixture samples, the $C_{v}$ increased with the $\sigma_{a}^{\prime}$ when the pore fluid was $1 \mathrm{M} \mathrm{NaCl}$, while it decreased at low $\sigma^{\prime}{ }_{a}$ levels when the pore fluid was distilled water. This shows that, as with the $m_{v}-\sigma_{a}^{\prime}$ trend, the $C_{v}-\sigma_{a}^{\prime}$ trend also depends on the mineral compositions, pore fluid chemistry, and stress levels.

\section{Data Availability}

The data used to support the findings of this study are available from the corresponding author upon request.

\section{Conflicts of Interest}

The authors declare that they have no conflicts of interest.

\section{Acknowledgments}

This research was funded by Vietnam National Foundation for Science and Technology Development (NAFOSTED) (grant no. 105.08-2019.315). We thank the staff at the Geotechnical lab, Yamaguchi University, Japan, for helping us conduct the experiments.

\section{References}

[1] H. A. Alawaji, "Swell and compressibility characteristics of sand-bentonite mixtures inundated with liquids," Applied Clay Science, vol. 15, no. 3-4, pp. 411-430, 1999.

[2] G. H. Bolt, "Physico-chemical analysis of the compressibility of pure clays," Géotechnique, vol. 6, no. 2, pp. 86-93, 1956.
[3] J. Chen, A. Anandarajah, and H. Inyang, "Pore fluid properties and compressibility of kaolinite," Journal of Geotechnical and Geoenvironmental Engineering, vol. 126, no. 9, pp. 798-807, 2000.

[4] C. Di Maio, L. Santoli, and P. Schiavone, "Volume change behaviour of clays: the influence of mineral composition, pore fluid composition and stress state," Mechanics of Materials, vol. 36, no. 5-6, pp. 435-451, 2004.

[5] J. Dutta and A. K. Mishra, "Consolidation behaviour of bentonites in the presence of salt solutions," Applied Clay Science, vol. 120, pp. 61-69, 2016.

[6] G. Mesri and R. E. Olson, "Consolidation characteristics of montmorillonite," Géotechnique, vol. 21, no. 4, pp. 341-352, 1971.

[7] R. G. Robinson and M. M. Allam, "Effect of clay mineralogy on coefficient of consolidation," Clays and Clay Minerals, vol. 46, no. 5, pp. 596-600, 1998.

[8] A. Sridharan and G. V. Rao, "Mechanisms controlling volume change of saturated clays and the role of the effective stress concept," Géotechnique, vol. 23, no. 3, pp. 359-382, 1973.

[9] Y.-H. Wang and W.-K. Siu, "Structure characteristics and mechanical properties of kaolinite soils. I. Surface charges and structural characterizations," Canadian Geotechnical Journal, vol. 43, no. 6, pp. 587-600, 2006.

[10] A. Sridharan and M. S. Jayadeva, "Double layer theory and compressibility of clays," Géotechnique, vol. 32, no. 2, pp. 133-144, 1982.

[11] J. K. Mitchell and K. Soga, Fundamentals of Soil Behavior, Vol. 3, John Wiley \& Sons, New York, NY, USA, 2005.

[12] E. Tombácz and M. Szekeres, "Surface charge heterogeneity of kaolinite in aqueous suspension in comparison with montmorillonite," Applied Clay Science, vol. 34, no. 1-4, pp. 105-124, 2006.

[13] G. Spagnoli, T. Fernández-Steeger, H. Hu, M. Feinendegen, and R. Azzam, "Potential calculation according to the Gouy and the Stern model for kaolinite and smectite," Giornale di Geologia Applicata, vol. 13, pp. 87-91, 2010.

[14] S. Horpibulsuk, N. Yangsukkaseam, A. Chinkulkijniwat, and Y. J. Du, "Compressibility and permeability of Bangkok clay compared with kaolinite and bentonite," Applied Clay Science, vol. 52, no. 1-2, pp. 150-159, 2011.

[15] R.-D. Fan, Y. J. Du, K. R. Reddy, S. Y. Liu, and Y. L. Yang, "Compressibility and hydraulic conductivity of clayey soil mixed with calcium bentonite for slurry wall backfill: initial assessment," Applied Clay Science, vol. 101, pp. 119-127, 2014.

[16] M. R. Lodahl and K. K. Sørensen, "Effects of pore water chemistry on the unloading-reloading behaviour of reconstituted clays," in Proceedings of the XVII European Conference on Soil Mechanics and Geotechnical Engineering, Reykjavik, Iceland, September 2019.

[17] A. K. Mishra, M. Ohtsubo, L. Li, and T. Higashi, "Effect of salt concentrations on the permeability and compressibility of soil-bentonite mixtures," Journal-faculty of Agriculture Kyushu University, vol. 50, no. 2, p. 837, 2005.

[18] A. K. Mishra, M. Ohtsubo, L. Y. Li, T. Higashi, and J. Park, "Effect of salt of various concentrations on liquid limit, and hydraulic conductivity of different soil-bentonite mixtures," Environmental Geology, vol. 57, no. 5, pp. 1145-1153, 2009.

[19] A. K. Mishra, M. Ohtsubo, L. Li, and T. Higashi, "Controlling factors of the swelling of various bentonites and their correlations with the hydraulic conductivity of soil-bentonite mixtures," Applied Clay Science, vol. 52, no. 1-2, pp. 78-84, 2011.

[20] N. Shariatmadari, M. Salami, and F. M. Karimpour, "Effect of inorganic salt solutions on some geotechnical properties of 
soil-bentonite mixtures as barriers," International Journal of Civil Engineering, vol. 9, no. 2, pp. 103-110, 2011.

[21] X. Li, G. Cai, A. J. Puppala, and S. Liu, "Compression behavior of reconstituted soils mixed with bentonite for a cutoff wall in a landfill site," Environmental Earth Sciences, vol. 77, no. 10, p. 390, 2018.

[22] Y.-T. Kim and T.-H. Do, "Effect of leaching on the compressibility of busan clay," KSCE Journal of Civil Engineering, vol. 14, no. 3, pp. 291-297, 2010.

[23] J. Liua and A. Ahmad, "Impact of salinity level in pore fluid on the compressibility of Champlain sea clay," in Proceedings of the XVI Pan-American Conference on Soil Mechanics and Geotechnical Engineering (XVI PCSMGE), p. 204, Cancun, Mexico, 2019.

[24] J. R. Mallick and M. S. Islam, "Effect of salinity on the compressibility and permeability characteristics of a coastal soil from Bangladesh," in Proceedings on International Conference on Disaster Risk Management, pp. 202-205, Dhaka, Bangladesh, 2019.

[25] J. G. Moore, J. D. Brown, and M. A. Rashid, "The effect of leaching on engineering behaviour of a marine sediment," Géotechnique, vol. 27, no. 4, pp. 517-531, 1977.

[26] J. K. Torrance, "A laboratory investigation of the effect of leaching on the compressibility and shear strength of Norwegian marine clays," Géotechnique, vol. 24, no. 2, pp. 155-173, 1974.

[27] N. T. Nu, N. T. Duong, and N. Van Phong, "The effects of salt contents on the geotechnical properties of some soft soils in the coastal area of Vietnam," Journal of Mining and Earth Sciences, vol. 60, no. 6, pp. 51-60, 2019.

[28] N. N. Truc, L. Mihova, T. Mukunoki, and D. M. Do, "Effect of saline intrusion on the properties of cohesive soils in the Red River Delta, Vietnam," Marine Georesources \& Geotechnology, vol. 38, no. 1, pp. 23-39, 2020.

[29] Y. Yukselen-Aksoy, A. Kaya, and A. H. Ören, "Seawater effect on consistency limits and compressibility characteristics of clays," Engineering Geology, vol. 102, no. 1-2, pp. 54-61, 2008.

[30] Japanese Geotechnical Society, JGS 0560-2009, Method for Consolidated Constant-Volume Direct Box Shear Test on Soils, Japanese Geotechnical Society, Tokyo, Japan.

[31] J. T. Germaine and A. V. Germaine, Geotechnical Laboratory Measurements for Engineers, John Wiley \& Sons, New York, NY, USA, 2009.

[32] N. T. Duong, M. Suzuki, and N. Van Hai, "Rate and acceleration effects on residual strength of kaolin and kaolinbentonite mixtures in ring shearing," Soils and Foundations, vol. 58, no. 5, pp. 1153-1172, 2018.

[33] N. T. Duong and M. Suzuki, "Rate effect on the residual interface strength between two different soil layers," in Geotechnics for Sustainable Infrastructure Development, pp. 985-992, Springer, Berlin, Germany, 2020.

[34] M. Suzuki, N. Van Hai, and T. Yamamoto, "Ring shear characteristics of discontinuous plane," Soils and Foundations, vol. 57, no. 1, pp. 1-22, 2017.

[35] Japanese Geotechnical Society, JGS 0411, Test Method for OneDimensional Consolidation Properties of Soils Using Incremental Loading, Japanese Geotechnical Society, Tokyo, Japan, 2009.

[36] ASTM International, ASTM D2216, Standard Test Methods for Laboratory Determination of Water (Moisture) Content of Soil and Rock by Mass, ASTM International, West Conshohocken, PA, USA, 2010
[37] ASTM International, ASTM D4318, Standard Test Methods for Liquid Limit, Plastic Limit, and Plasticity Index of Soils, ASTM International, West Conshohocken, PA, USA, 2010.

[38] I. Noorany, "Phase relations in marine soils," Journal of Geotechnical Engineering, vol. 110, no. 4, pp. 539-543, 1984.

[39] Z.-S. Hong, L.-L. Zeng, Y.-J. Cui, Y.-Q. Cai, and C. Lin, "Compression behaviour of natural and reconstituted clays," Géotechnique, vol. 62, no. 4, pp. 291-301, 2012.

[40] Z.-S. Hong, J. Yin, and Y.-J. Cui, "Compression behaviour of reconstituted soils at high initial water contents," Géotechnique, vol. 60, no. 9, pp. 691-700, 2010.

[41] V. Sreedharan and S. Puvvadi, "Compressibility behaviour of bentonite and organically modified bentonite slurry," Géotechnique, vol. 63, no. 10, pp. 876-879, 2013.

[42] A. Casagrande, "The determination of pre-consolidation load and it is practical significance," in Proceedings of the International Conference on Soil Mechanics and Foundation Engineering, Cambridge, MA, USA, June 1936.

[43] A. Sridharan and K. Prakash, "Influence of clay mineralogy and pore-medium chemistry on clay sediment formation," Canadian Geotechnical Journal, vol. 36, no. 5, pp. 961-966, 1999.

[44] S. M. Woo, Z. C. Moh, and T. Burmungsup, "Effects of soil structure on compressibility of an artificially sedimented clay," in Proceedings of International Symposium on Soft Clays, pp. 311-325, Bangkok, Thailand, 1977.

[45] L. A. van Paassen and L. F. Gareau, "Effect of pore fluid salinity on compressibility and shear strength development of clayey soils," in Engineering Geology for Infrastructure Planning in Europe, pp. 327-340, Springer, Berlin, Germany, 2004.

[46] B. Tiwari and B. Ajmera, "Effects of saline fluid on compressibility of clay minerals," Environmental Geotechnics, vol. 1, no. 2, pp. 108-120, 2014.

[47] D. W. Taylor, Fundamentals of Soil Mechanics, Vol. 66, LWW, Philadelphia, PA, USA, 1948.

[48] K. Terzaghi, R. B. Peck, and G. Mesri, Soil Mechanics in Engineering Practice, John Wiley \& Sons, New York, NY, USA, 1996.

[49] A. Nakase, O. Kusakabe, and S. F. Wong, "Centrifuge model tests on bearing capacity of clay," Journal of Geotechnical Engineering, vol. 110, no. 12, pp. 1749-1765, 1984.

[50] A. M. Samarasinghe, Y. H. Huang, and V. P. Drnevich, "Permeability and consolidation of normally consolidated soils," Journal of the Geotechnical Engineering Division, vol. 108, no. 6, pp. 835-850, 1982.

[51] A. Sridharan, P. V. Sivapullaiah, and V. K. Stalin, "Effect of short duration of load increment on the compressibility of soils," Geotechnical Testing Journal, vol. 17, no. 4, pp. 488-496, 1994. 